United States of North America will do well to bear in mind the success of fire conservancy in India. Systematic forest management is a difficult undertaking, which has many enemies. Nevertheless success is possible, and if these forestry manuals facilitate the attainment of success in this business, their authors will have reason to be well satisfied with their work.

DIETRICH BRANDIS.

\section{THE DEVELOPMENT OF BUTTERFLIES} UNDER ARTIFICIAL CONDITIONS.

$\mathrm{HE}$ effects which cold and heat, applied to the pupa, produce in the colours and patterns of the imaginal wings, have been studied for many years and by many naturalists. Weismann in 1875 published an account of his own experiments, and those conducted by others, in an essay which was published in this country in 1882 among the "Studies in the Theory of Descent," translated and edited by Meldola.

The experiments described by Weismann have been repeated and greatly extended by Merrifield (Trans. Ent. Soc. Lond., I888, I889, I89 I, I892, I893, I894), while Dixey has published interesting observations on the phylogenetic significance of some of the results obtained (Ibid., I 893, I 894).

While these careful and successful experiments were being conducted in this country, Standfuss of Zurich has been independently engaged on the same research, employing in many cases the very species which had been used by Merrifield. Standfuss's paper, appearing in 1894 , has been translated by Dixey, and, after revision by the author, has been published, with an introductory note by Merrifield, in the pages of The Entomologist for March, April, and May 1895. The editors of this journal are to be congratulated on the effort they have made to lay before their readers some of the interesting results of entomological research conducted by continental naturalists. We may hope that the attempt which has been so successfully made, will be frequently repeated.

(I) The Egg.-The eggs of four species of moth (Arctia fasciata, Dasychira abietis, Lasiocampa pruni, and L. pini) were exposed to a high temperature, $34^{\circ} \mathrm{C}$. $\left(93^{\circ} \mathrm{F}\right.$.), as they were being laid, and subsequently up to the time of hatching. The larvæ hatched in two-thirds or less of the normal time, and although the temperature remained normal, $25^{\circ} \mathrm{C}$. $\left(77^{\circ} \mathrm{F}\right.$.), throughout the subsequent stages, 7 I per cent. of fasciata, 90 of abietis, Ioo of pruni, and 8I of pini emerged as imagos in that year, the remainder hybernating as larva ; as against $23,12,64$, and 28 per cent. respectively, when eggs from the same parents had been laid and kept at a temperature of $22^{\circ} \mathrm{C}$. $\left(72^{\circ} \mathrm{F}\right.$.) and at $25^{\circ} \mathrm{C}$. during the subsequent stages. This persistence throughout the later stages of the hurrying-up of development, when the conditions which originally started it had ceased at the beginning of larval life, is very remarkable, and it is unfortunate that the author should have contented himself with giving his results in percentages instead of the actual numbers obtained. This criticism applies to nearly all the results recorded in the paper.

There was no evidence that the imagos were otherwise influenced by the condition of the ova.

(2) The Larva.-Experiments with an increased temperature generally shortened the period of larval development and reduced the size of the imago. From these experiments the author infers that the great difference in size between certain closely allied species (e.g. Boarmia consortaria as compared with the much larger $B$. roboraria) has been produced by the larva reacting in a different manner under changes of temperature, so that some acquired long and the others short larval periods. It would appear that the evidence in favour of this conclusion has not been sufficiently sifted, NO. I 380 , VOL. 53$]$ and that certain obvious difficulties raised by this interpretation have been overlooked.

Certain changes in form, colour, and marking are also described as following the temperature conditions of the larvæ. In these cases, however, the author does not appear to be giving the results of his own experiments, but reasoning from the differences observed in the several broods of many species appearing at different seasons, and especially contrasting the forms produced from hybernated larvæe with those produced without hybernation. In these cases it is the duty of the naturalist to determine by means of artificial experiments whether the observed changes are entirely due to conditions of temperature, and whether the larval stage alone is of importance.

Many experiments were made with foods, polyphagous larvæ being fed on poisonous or acrid plants, on such abnormal diet as raw meat, or on plants which had absorbed solutions of various substances. The perfect insects "often enough showed a failure in size or general colouring, but in no case any noteworthy variation in tint or pattern."

The effects of light transmitted through glass of different colours were negative, although the larva were exposed to these conditions "from the time when they were quite small."

(3) The Pupa.-By far the most complete results were obtained by subjecting the pupa to various degrees of temperature.

The effects obtained with Papilio machaon and Vanessa antiopa are of especial interest, inasmuch as Merrifield's material had been inadequate and his results, as regards these species, negative.

Seventeen pupæ of $P$. machaon, kept at a temperature of $37^{\circ} \mathrm{C} .\left(98^{\circ}-99^{\circ} \mathrm{F}\right.$.) from the time when the cuticle hardened at the beginning of pupation, produced in seven to ten days fifteen insects, which were much lighter in colour than usual, owing to the development of a yellow powdering which obscured many of the dark markings on the upper and under sides of the wings, and the body. Changes in form are also described, including a marked lengthening of the "tail" of the hind wing. "Some of these specimens . . . bear a perfect resemblance to those that fly in August in the neighbourhood of Antioch and Jerusalem." The pupa subjected to cold (for twentyeight days) produced only two imagos, and these resembled the Swiss and German forms emerging from hybernated pupæ.

The pupæ of Vanessa antiopa, after being exposed to heat $\left(37^{\circ} \mathrm{C}\right.$. or $98^{\circ}-99^{\circ} \mathrm{F}$.) for forty-eight hours, produced, ten days later, butterflies in which the marginal blue appeared to be reduced, and the yellow border broadened, but in neither case to a greater extent than in nature. Among these individuals, however, 2 per cent. presented a very remarkable variation, which Standfuss has named var. daubi. This well-marked form is constantly produced when the pupa were exposed to heat (as above) for sixty hours, and then kept at a temperature of $24^{\circ} \mathrm{C} .\left(75^{\circ} \mathrm{F}\right.$.). Such pupa produced the var. daubi in twelve days. The upper surface of both wings is greatly darkened, becoming almost black, the blue spots are much reduced and have a violet tinge, but the most remarkable change occurs in the yellow border, which is extremely darkened, so as to leave, in extreme cases, only a small remnant of yellow scales. The under side is as much darkened as the upper; and certain changes in the form of the wings are also described.

Cold produced very different effects according to the time of exposure. The most interesting results, and those which most strongly suggest the appearance of allied species ( $V$. urtice, $V$. polychloros), followed the shortest exposure of twenty-nine to thirty-four days in the refrigerator. In these cases the brown ground colour became lighter, and the blue spots (much enlarged on the 
fore wing) acquired dark borders. At the same time traces of dark spots, like those of the allied species, appeared in certain individuals, while the under side, especially of the hind wing, underwent changes which are also described in $V$.io, gaining a pattern in brown scales which recalled that of $V$.polychloros, \&c. A longer period (thirtynine days) produced far less interesting results, the blue being increased, the yellow border diminished, and the ground colour darkened. Forty-four days in the refrigerator produced more marked effects in the same direction, the blue spots of the hind wing being so increased that they project into the yellow border. The ground colour of both upper and under sides is much darkened. This beautiful variety is called by the author var. roederi.

As regards other species of butterflies, Standfuss's results afford valuable confirmation of those obtained by Merrifield. Thus heat $\left(37^{\circ} \mathrm{C}\right.$.) produced light-coloured imagines of Grapta C-album with less sharply-defined markings and less deeply indented wing margins; while cold produced opposite effects, the clark colours of the under sides of the wings being often "mingled with moss-green tints."

In Vanessa polychloros, heat $\left(37^{\circ}\right.$ C. $)$ reduced the marginal blue spots and the dark wing-border, and brightened the colour of the upper sides of the wings, cold producing the opposite results.

In $V$. urtice, more extreme effects in the same direction were witnessed, heat causing an approach towards the var. ichnusa, and to a certain extent towards $V$. io; while cold produced butterflies which recalled the North American $V$. milberti It was noteworthy that pupre kept on ice for forty-two days (emerging thirteen to fourteen days afterwards), produced less deviation from the normal than those which had been exposed for only thirty-two days, and emerged nine to ten days afterwards. In neither case is there any record of the numbers of individuals made use of.

In $V$. io, heat produced little result, while cold (thirtyfive days in refrigerator) caused most interesting changes in the direction of $V$. urtice and $V$. polychloros. A longer period of cold (forty-two days) still further intensified these changes, which affected the under as well as the upper sides of the wings, the well-known uniform darkness of $V$. io giving place in the most extreme examples to a sharply-defined pattern in brown scales, far more suggestive of the above-mentioned species of Vanessa.

In Vanessa atalanto, heat greatly reduced the blue in margin of the fore wing, widened the red band, and reduced the apical white spots; thus approximating towards $V$. callirrhöe. Cold (thirty-one days) conversely increased the large white spot, reduced the red band by the encroachment of dark shades, and increased the blue. A longer period of cold (forty-two days) produced ten almost normal insects and a single extreme form. It would therefore appear that less effects were, on the whole, produced by the longer period, although the materials for a valid comparison are absent, inasmuch as the author only informs us that there was "much individual variation" in the results of the shorter period.

In Vanessa cardui a higher temperature $\left(40^{\circ} \mathrm{C} .=\right.$ $\mathrm{IO}^{\circ} \mathrm{F}$.) was made use of for two periods of six hours, alternating with one of twelve hours at the normal temperature (about $22^{\circ} \mathrm{C} .=72^{\circ} \mathrm{F}$ ). Only two pupae out of forty-two failed to emerge, although twelve produced crippled butterflies. Four specimens were of the var. elymi, the remainder normal. In another experiment with $36^{\circ}$ to $37^{\circ} \mathrm{C}$. for sixty hours, a remarkably pale form was produced ; while in other cases the red colour, often acquiring a brownish tinge, was increased in extent on both upper and under surface of the wings. Cold (twentythree days), on the other hand, darkened both sides of the wings. A longer period of cold (twenty-eight NO. I 380 , VOL. 53$]$ days) produced, on the whole, rather more extreme effects.

In Argynnis aglaia, heat (four days at $36^{\circ} \mathrm{C}$.) produced very little effect, the ground colour of the upper sides of the wings being lighter, the greyish-green shades of the under sides darker and more conspicuous than usual. After twenty-eight days of cold, only three uninjured insects emerged from twenty-one pupæ; in these the ground colour was unaltered, the black spots at the base of the fore wing enlarged, while the greyish-green shades, described above, gained a brown tinge. After a longer period of cold (forty-two days), two insects emerged from twelve pupæ, and these showed far more extreme effects in the darkening of both upper and under sides of the wings.

The pupæ of Dasychira abietis were killed by heat $37^{\circ} \mathrm{C}$., while cold (forty-two days) tended to darken the insects.

Some experiments were also made upon the effects of comparative dryness and moisture upon the pupæ. Large numbers of pupæ of Satumia pavonia were kept very dry from June to the end of September, and were then exposed to moisture; a treatment which the author believes, from repeated experiments, causes about I per cent. of the moths to emerge in about ten to twenty days, instead of hybernating. In these moths the pattern was " not sharply outlined, but more or less washed out and confused."

Towards the end of the paper the author gives a brief and general account of the results obtained by subjecting the pupæe to heat and cold. He summarises the various classes of effects as follows:

(I) "Seasonal forms" similar to those which are known to occur in nature ( $V . C$-album and $P$. machaon to some extent).

(2) Local forms and races similar to those which occur constantly in certain localities ( $V$. urtice, cardui, and to some extent $P$. machaon and $V$. antiopa).

(3) Entirely exceptional forms or "aberrations," also occurring from time to time in nature $(V$. io, $V$. cardui, argynnis aglaia).

(4) Phylogenetic forms, not now occurring on the earth, "but which may either have existed in past epochs, or may perhaps be destined to arise in the future" ( $V$. io, $V$. antiopa, $V$. atalanta).

This portion of the paper, although of interest, is not equal to the experimental portion, and cannot be in any way compared with Dixey's careful consideration of the results of Merrifield's experiments.

It is to be hoped that Dr. Standfuss will continue his experiments on this most interesting subject. E. B. P.

\section{A NEW SYNOPSIS ANIMALIUM-DAS TIERREICH.}

$\mathrm{F} R O M$ rough calculations lately made by the contributors to the Zoological Record, it would appear that some 360,000 species of animals have been described by naturalists up to the present date. To arrange all these species on a uniform system, and to add descriptions and other necessary particulars to each of them, would appear to be almost an herculean task. Yet it has been undertaken, we are told, by the German Zoological Society, which has entered into an agreement with Mess $\hookrightarrow$. Friedländer and Son for the publication of such a work. Prof. F. E. Schultze, of Berlin, has been selected as general editor of "Das Tierreich," and will be assisted by numerous sub-editors in the different departments of zoology. Each of these sub-editors again will invite the assistance of specialists in the groups assigned to his charge, so that a very large number of naturalists will assist in this gigantic undertaking. It is proposed to issue the first parts of the work in 1897 , and it is expected that at least twenty-five 